\title{
SUBFOSSIL CHIRONOMID STRATIGRAPHY OF A SMALL ACID LAKE IN SOUTHERN FINLAND
}

\author{
HEIKKI OLANDER
}

\begin{abstract}
Olander, Heikki: Subfossil chironomid stratigraphy of a small acid lake in southern Finland. Bull. Geol. Soc. Finland, 64, Part 2, 183-188.

Chironomid analysis was used to study ecological changes in shallow oligotrophic Lake Orajärvi in Espoo, southern Finland. A $53 \mathrm{~cm}$ long sediment core for chironomid analysis was obtained at $6 \mathrm{~m}$ depth.

Changes in chironomid composition of the Lake Orajärvi are related to temperature changes and anthropogenic acidification. Decline of Microtendipes and emergence of Heterotrissocladius at $30-35 \mathrm{~cm}$ depth are due to deteriorating climate after Holocene climatic optimum. Most recent changes in chironomid fauna can be related to strong human induced acidification of the lake, which has led to domination of Dicrotendipes and Psectrocladius.

Chironomid analysis, which mostly has been used in deep stratified lakes, seems to be a valid method also in shallow unstratified lakes.
\end{abstract}

Key words: paleolimnology, Chrionomidae, lake sediments, stratigraphy, palaeoclimatology, acidification, Holocene, Lake Orajärvi, Espoo, Finland.

Heikki Olander: Geological Survey of Finland, SF-02150 Espoo, Finland.

\section{Introduction}

Chironomid analysis (Chironomidae: Diptera) has been carried out for quite a long time. Nevertheless its value as a palaeolimnological research method has largely been underestimated, primarily because of an inadequate knowledge of the ecology and taxonomy of chironomid larvae. During the few last decades however the situation has improved because of many studies about chironomid ecology.

Chironomid larvae are suitable for palaeolimnological research in reconstructing the environmental conditions at the time of sedimentation because: 1) Chironomid communities in individual lakes are highly diverse, so that both species and individuals are numerous; 2) Different species are adapted to different kinds of ecological environments; 3) Chironomids are able to react to changing environmental conditions extremely rapidly when compared with plants for example; 4) Chironomid head capsules have a relatively high pre- sevation potential in bottom sediments and may remain recognizable for a long time; 5) It is possible to identify chironomid remains even to species level.

In deep stratified lakes the oxygen condition of the hypolimnion correlates well with lake's trophic status and chironomid fauna (Hofmann 1986, Hofmann 1988). Thus changes in profundal chironomid faunas have been studied more than changes in littoral or sublittoral faunas. The ecology of profundal species is therefore better known, which makes it difficult to reconstruct past conditions in shallow unstratified lakes. The ecology of littoral chironomids is often more complex than that of profundal species. In shallow lakes other factors than trophic status may be more important, for example water temperature and sedimentation (Hofmann 1986).

Chironomid analysis has been used to study anthropogenic eutrophication (Alhonen and Haavisto 1969 , Wiederholm and Eriksson 1979, Warwick 1980, Brodin 1982, Dévai and Moldován 1983, 


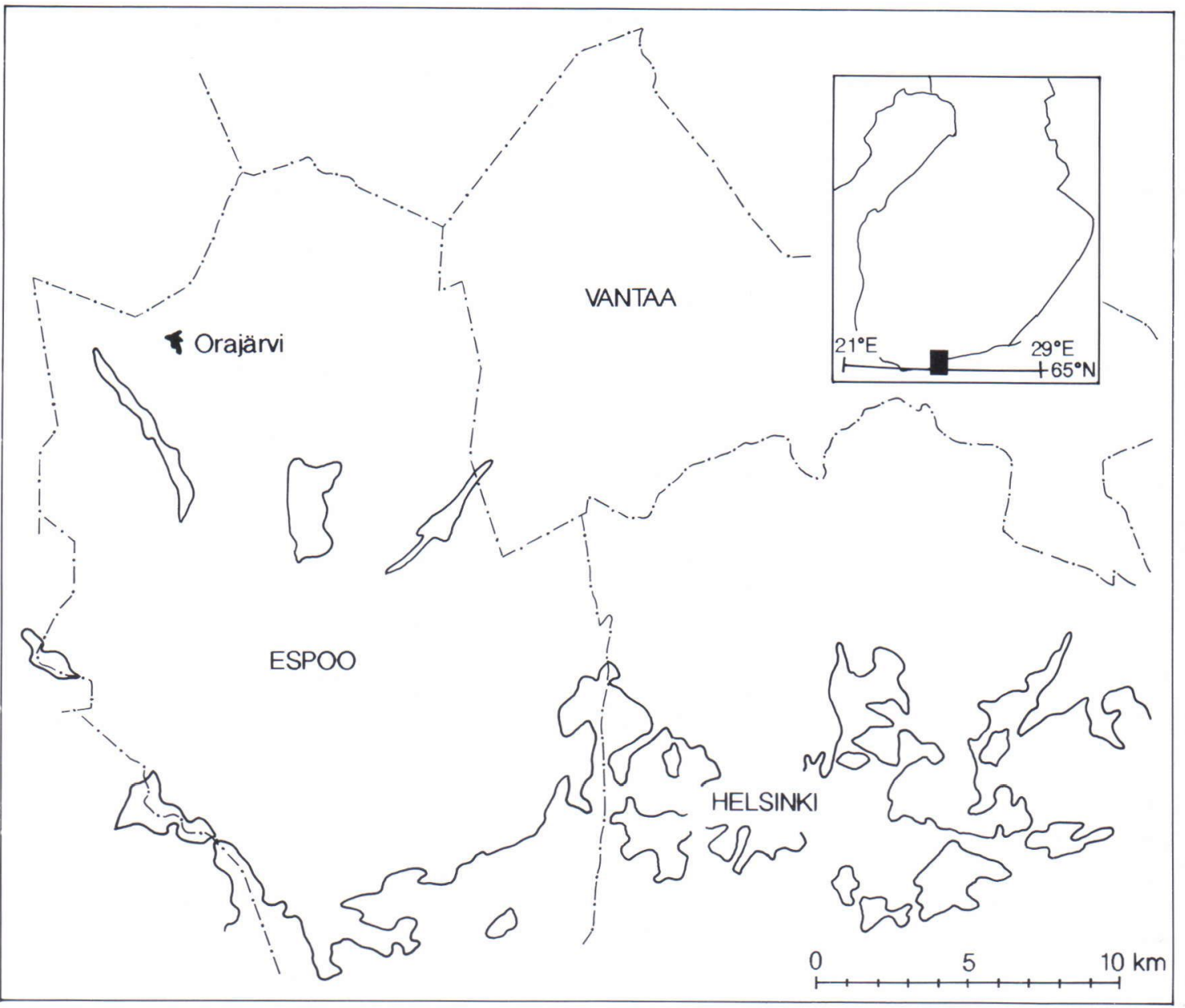

Fig. 1. Location of Lake Orajärvi.

Meriläinen 1987, Räsänen et al. 1992), acidification (Henrikson et al. 1982, Charles et al. 1990, Brodin 1990, Johnson et al. 1990), salinity (Paterson and Walker 1974) and climatic changes (Walker and Mathewes 1987, Walker et al. 1991a, Walker et al. 1991b). Many lake classifications based on chironomids have been presented, but they are valid only in deep stratified lakes.

The aim of this study was to adapt and apply chironomid analysis to a shallow unstratified lake and examine anthropogenic acidification and climatic changes.

\section{Study site}

Lake Orajärvi is situated in the city of Espoo, in the forested area of Nuuksio, about $25 \mathrm{~km} \mathrm{NW}$ of Helsinki. It is a small, unstratified, oligotrophic lake with a maximum depth of $6,0 \mathrm{~m}$, an area of $0,22 \mathrm{~km}^{2}$ and an elevation of $87 \mathrm{~m}$ above sea level. The catchment area is neither inhabited nor cultivated. The sedimentation rate in Orajärvi is only about $0,1-0,2 \mathrm{~mm} / \mathrm{a}$. Orajärvi has become heavily acidified during the last decades because of acid rain. At the sediment surface there is a $5 \mathrm{~cm}$ thick 
black gyttja layer, black colour being derived from airborne coal dust (Tolonen and Jaakkola 1983). At the end of the 1970's Lake Orajärvi was known for its large perch but the fish population has subsequently disappeared (Tolonen and Jaakkola 1983).

\section{Sampling}

Sediment core was taken from Orajärvi in October 1990 using a crust-freeze corer (Saarnisto 1975). Water depth at the sampling site was $6 \mathrm{~m}$. The length of the continuous sample was $53 \mathrm{~cm}$ and in addition to it one separate sample from 69$72 \mathrm{~cm}$ depth was obtained. Visible structures were described at the sampling site. A subsample for radiocarbon dating was taken from $27-30 \mathrm{~cm}$ depth and another subsample from $69-72 \mathrm{~cm}$ depth. Subsamples for chironomid, water content and loss-on-ignition analyses were taken from 0 1 and $1-2 \mathrm{~cm}$ depths and then $3 \mathrm{~cm}$ thick sections continuously down to $53 \mathrm{~cm}$ depth. Sample sizes for chironomid analysis varied between 2$20 \mathrm{~g}$. Radiocarbon age determinations were made at the Radiocarbon laboratory of the Geological Survey of Finland.

\section{Preparation}

Preparation was done using methods described by Wiederholm and Eriksson (1979), Hofmann (1986), Walker and Paterson (1985) and Walker (1987). Every subsample was boiled in hot $\left(60^{\circ} \mathrm{C}\right)$ $10 \% \mathrm{KOH}$ - solution for one hour to remove organic material. A magnetic stirrer was used when necessary to deflocculate sediment. Samples were then sieved through 210 and $125 \mu \mathrm{m}: \mathrm{n}$ sieves to reduce sample size. Remaining material was examined under a Wild stereo microscope using 10 50 fold magnification. All head capsules were handpicked and placed on microscope slides using small forceps and mounted in Euparal.

Chironomid identification, to species level when possible, was made using Hofmann (1971), Sae-

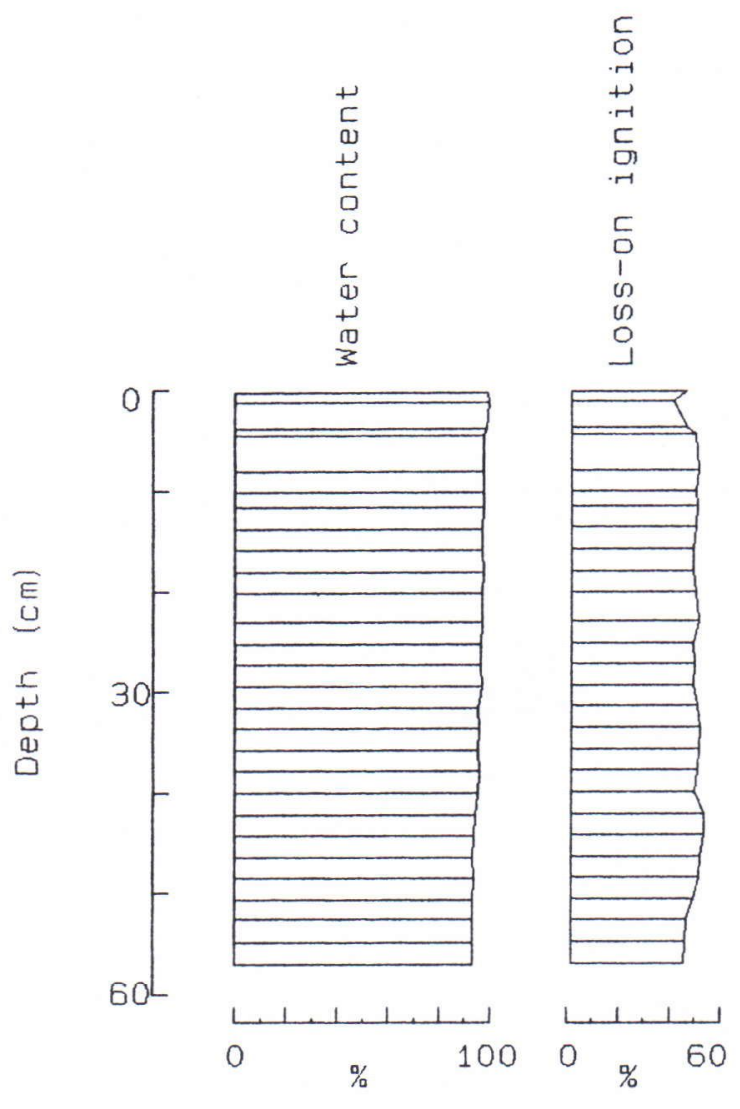

Fig. 2. Lake Orajärvi sediment water content and loss-on- ignition diagrams.

ther (1975) and Wiederholm (1983). Head capsules of the subfamily Orthocladiinae split easily into two equal parts, a fact which was taken into account during identification.

\section{Results}

\section{Sediment}

A layer about $5 \mathrm{~cm}$ thick at the surface of the sediment consisted of black striped fine detritus gyttja and underneath that was a homogeneous dark green fine detritus gyttja. Water content in sediment was rather stable throughout the whole 


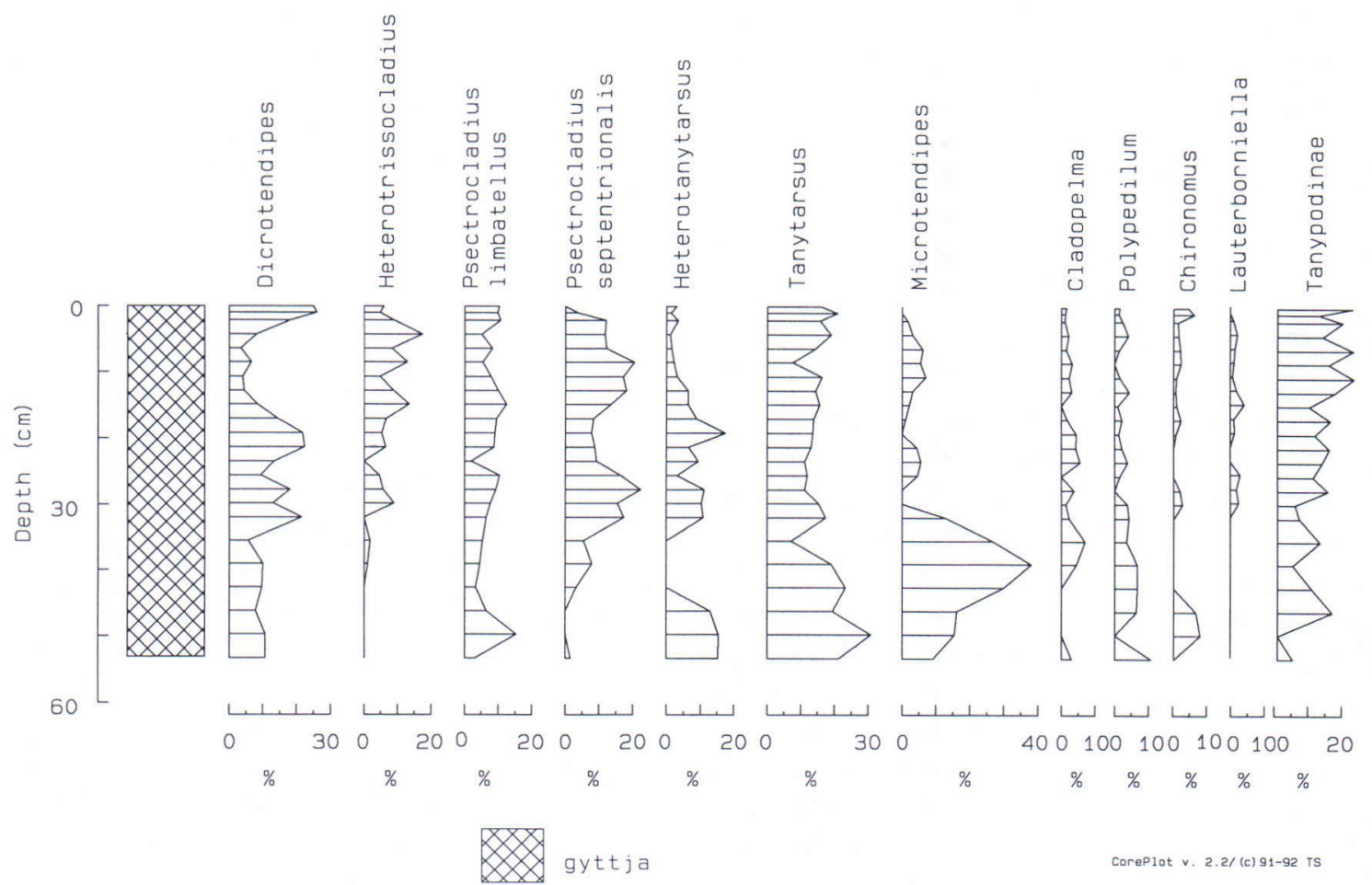

Fig. 3. Lake Orajärvi chironomid diagram.

sample variying between $90-95 \%$, with a tendency to steadily increase towards the surface (Fig. 2). Organic contents also increase slightly towards the surface varying between $40-53 \%$. the organic content of the surface samples is however lower than elsewhere in the profile. The radiocarbon age at $27-30 \mathrm{~cm}$ depth was $2180 \pm 100$ years ( $\mathrm{Su}-1988)$ and at $69-72 \mathrm{~cm}$ depth $6560 \pm 70$ years ( $\mathrm{Su}-1989)$.

\section{Chironomids}

Altogether 2216 chironomid head capsules were counted. The most common genera were Psectrocladius, Heterotrissocladius, Dicrotendipes, $\mathrm{Mi}$ crotendipes and Tanytarsus. Members of the Tanypodinae-subfamily were also common. Heterotrissocladius is absent below $45 \mathrm{~cm}$ depth and its relative abundance increases towards the sediment surface (Fig. 3). Dicrotendipes is the most common genus in the uppermost samples and is also common at $30-20 \mathrm{~cm}$ depth, but between 20 $10 \mathrm{~cm}$ its proportion decreases strongly. Increasing relative proportions of Psectrocladius limbatellus, $P$. septentrionalis and Tanytarsus sp. towards the surface are distinctive features of the profiles. Microtendipes is the most common genus at 45 $35 \mathrm{~cm}$ depth, but at $35 \mathrm{~cm}$ depth its proportion decreases rapidly. The Tanypodinae-subfamily is common in the whole sediment section with an increase towards the surface.

\section{Discussion}

Changes in water and organic content are most likely due to compaction and diagenesis of the sediment. These minor changes also clearly indicate that sedimentation has been rather stable throughout the portion of the lake's history studied here. According to Tolonen and Jaakkola (1983) the $\mathrm{pH}-$ 
value in the sediment decreases from 6,1 at $15 \mathrm{~cm}$ depth to 5,0 at $0 \mathrm{~cm}$ depth. It is probable that a similar change has occurred in lake water too.

In shallow lakes climate is an important factor influencing chironomid faunas (Hofmann 1986, Walker and Mathewes 1987a, Walker and Mathewes 1987b, Hofmann 1988). The studied core extends back, according to the radiocarbon age determinations, the warm Atlantic period, so that climatic changes have certainly had an effect on the chironomids of Lake Orajärvi. The age determinations are however scarce, which may render the results questionable.

Dicrotendipes and Psectrocladius, which are the most common genera at the sediment surface and also in the recent chironomid population of the Lake Orajärvi (Jarmo Meriläinen, pers. comm.), have possibly benefited by the disappearance of fish population; their larvae are rather large and therefore natural prey for perch. Because of their size they can also tolerate low $\mathrm{pH}$-values. Another reason for the dominance of Dicrotendipes may be that it emerges in June-July (Henrikson et al. 1982) and not in early spring when $\mathrm{pH}$ values are at their lowest. Increasing proportions of Dicrotendipes and Psectrocladius are typical features in acidified lakes.

Heterotrissocladius is totally absent from the samples below $45 \mathrm{~cm}$, which may be related to a warm period at the Holocene climatic optimum. The warmest adapted species of Heterotrissocladius is still restricted to relatively cold waters (Walker and Mathewes 1987a). The marked decrease in the proportion of Microtendipes at 30-

\section{References}

Alhonen, P. \& Haavisto, M.-L. 1969. The biostratigraphical history of Lake Otalampi in southern Finland, with special reference to the remains of subfossil midge fauna. Bulletin of the Geological Society of Finland 41, 157-164.

Berglund, B.E.(ed.). 1986. Handbook of holocene palaeoecology and palaeohydrology. Wiley, Chichester. $869 \mathrm{pp}$.

Brodin, Y., 1982. Palaeoecological studies of the recent development of the Lake Växjösjön. IV. Interpretation of the eutrophication process through the analysis of subfossil
$35 \mathrm{~cm}$ depth is possibly related to a deteriorating climate following climatic optimum. According to Walker et al. (1991a) Microtendipes is classified as a temperate genus. Tanytarsus were impossible to identify to species level and were not used in making interpretations. The head capsules of the subfamily Tanypodinae are fragile, which greatly reduces their value as indicators. In this study they were therefore left unstudied.

Decreasing diversity of zoobenthos is a typical feature of acidic lakes (Henrikson et al. 1982, Brodin 1990). In Lake Orajärvi however, this kind of trend is not apparent, probably because of the very slow sedimentation rate compared with the sample intervals. Decreasing total number/g dry matter in the lowermost samples is possibly due to mechanical or chemical dissolution of the head capsules.

Through the acidification of the lake man has destroyed the fish population in Lake Orajärvi and this change in natural predation relationships has had effect on the composition of chironomid populations. Lowered ph-values in the lake may also have had direct effect on at least some chironomid genera. However the most striking changes in chironomid composition are caused by long-term climatic changes.

The chironomid fauna of Lake Orajärvi consists of littoral and sublittoral taxa. It is thus evident that chironomid analysis is a valid palaeolimnological method in shallow as well as in deep stratified lakes. Interpretation of results obtained by chironomid analysis should however be compared with results obtained by other methods. chironomids. Archiv für Hydrobiologie 93(3), 313-326.

Brodin, Y.-W., 1990. Midge fauna development in acidified lakes in northern Europe. Philosophical Transactions of the Royal Society of London B327, 295-298.

Charles, D.F., Binford, M.W.,Furlong,E.T.,Hites, R.A.,Mitchell, M.J., Norton, S.A., Oldfield, F., Paterson, M.J., Smol, J.P., Uutala, A.J., White, J.R., Whitehead,D.R.\& Wise, R.J., 1990. Palaeoecological investigation of recent lake acidification in the Adirondack Mountains, N.Y. Journal of Paleolimnology 3, 195-241.

Dévai, G.\& Moldován,J., 1983. An attempt to trace eutrophication 
in a shallow lake (Balaton, Hungary) using chironomids. Hydrobiologia 103, 169-175.

Henrikson, L., Olofsson, J.B., \& Oscarson, H.G., 1982. The impact of acidification on Chironomidae (Diptera) as indicated by subfossil stratification. Hydrobiologia 86, 223-229.

Hofmann, W., 1971. Zur Taxonomie und Palökologien subfossil Chironomiden (Dipt.) in Seesedimenten. Archiv für Hydrobiologie/Beig. Ergebnisse der Limnologie 6, 1-50.

Hofmann, W., 1986. Chironomid analysis. In: B.E. Berglund (ed.), Handbook on Holocene palaeoecology and palaeohydrology. Wiley, Chichester, pp. 715-727.

Hofmann, $W ., 1988$. The significance of chironomid analysis (Insecta: Diptera) for paleolimnologigal research. Palaeogeography, Palaeoclimatology, Palaeoecology, 62, 501-509.

Johnson, M.G., Kelso, J.R.M., McNeil, O.C. \& Morton, W.B., 1990. Fossil midge associations and the historical status of fish in acidified lakes. Journal of Paleolimnology 3, 113127.

Meriläinen, J.J., 1987. The profundal zoobenthos used as an indicator of the biological condition of Lake Päijänne. Biological Research Report from the University of Jyväskylä 10, 87-94.

Paterson,C.G.\&Walker, K.F., 1974. Recent history of Tanytarsus barbitarsus Freeman (Diptera:Chironomidae) in the sediments of shallow saline lake. Australian Journal of Marine and Freshwater Research 25, 315-325.

Räsänen, M., Salonen, V.-P., Salo, J., Walls, M. \& Sarvala, J., 1992. Recent history of sedimentation and biotic communities in Lake Pyhäjärvi, SW Finland. Journal of Paleolimnology 7, $107-126$.

Saarnisto, M., 1975. Pehmeiden järvisedimenttien näytteenottoon soveltuva jäädytysmenetelmä. Geologi $27,37-39$.

Saether, O.A., 1975. Nearctic and Palaearctic Heterotrissocladius (Diptera:Chironomidae). Fisheries Research Board of Canada Bulletin 193.

Tolonen, K.\& Jaakkola, T., 1983. History of lake acidification and air pollution studied on sediments in South Finland. Annales Botanici Fennici 20, 57-78.

Walker, I.R., 1987. Chironomidae (Diptera) in paleoecology. Quaternary Science Reviews 6, 29-40.

Walker, I.R. \& Mathewes, R.W., 1987a. Chironomidae and Postglacial Climate at Marion Lake, British Columbia, Canada. Quaternary Research 27, 89-102.

Walker,I.R.\& Mathewes, R.W., 1987b. Chironomids, Lake Trophic Status, and Climate. Quaternary Research 28, 431- 437.

Walker, I.R., Mott, R.J. \& Smol, J.P., 1991a. Alleröd-Younger Dryas Lake Temperatures from Midge Fossils in Atlantic Canada. Science 253, 1010-1012.

Walker,I.R., Smol, J.P., Engstrom, D.R. \& Birks, H.J.B., $1991 \mathrm{~b}$. An Assessment of Chironomidae as Quantitative Indicators of Past Climatic Change. Canadian Journal of Fisheries and Aquatic Sciences 48, 975-987.

Walker, I.R. \& Paterson, C.G., 1985. Efficient separation of subfossil Chironomidae from lake sediments. Hydrobiologia 122, 189-192.

Warwick, W.F., 1980. Chironomidae (Diptera) responses to 2800 years of cultural influence; a palaeolimnological study with special reference to sedimentation, eutrophication, and contamination processes. The Canadian Entomologist 112,11931238.

Wickström, K. \& Tolonen, K., 1987. The history of airborne polycyclic aromatic hydrocarbons $(\mathrm{PAH})$ and perylene as recorded in dated lake sediments. Water, Air and Soil Pollution 32, 155-175.

Wiederholm, T. (ed.), 1983. Chironomidae of the Holarctic region. Keys and diagnoses. Part 1 - Larvae. Entomologica Scandinavica Supplement 19.

Wiederholm, T. \& Eriksson, L., 1979. Subfossil chironomids as evidence of eutrophication in Ekoln Bay, central Sweden. Hydrobiologia 62, 195-208.

Received June 8, 1992

Revision accepted July 13, 1992 